\title{
AGNĖ ALIJAUSKAITÉ
}

Vilniaus universitetas, Lietuva

Vilnius University, Lithuania

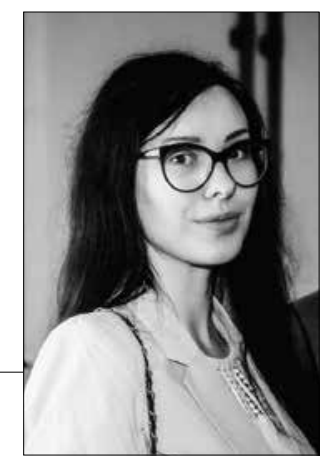

\section{RICHARDO RORTY SĄMONÉS FILOSOFIJA KAIP METAFILOSOFINIS PROJEKTAS}

\author{
Richard Rorty's Philosophy of Mind as a Metaphilosophical Project
}

\section{SUMMARY}

This article argues that Rorty's philosophy of mind is possible as a metaphilosophical project. It trespasses the limits of physicalism and yet opposes philosophical scholasticism. Rorty's physicalism is grounded on a metaphilosophical motivation and aims to show that physical descriptions protect against unjustified pretensions to a transcendentally engaged, considered to be objective, universally applicable knowing. While defending Rorty's eliminativism from criticism aimed at his presupposed scientism, the article discusses the possibility of "mind" as an empty concept. The article concludes that, in the context of Rorty's philosophy, the concept of mind should be considered as idealistic and naturalistic, not indicating any concrete content and therefore immune to materialistic criticism. However, despite the physical vocabulary aimed at expanding the problematics of mind, the full self-knowledge at which the scientific knowledge is aimed is unachieved. This leaves space for philosophical, theological and descriptions of mind.

\section{SANTRAUKA}

Šiame straipsnyje teigiama, kad Rorty sąmonės filosofija įmanoma kaip metafilosofinis projektas, pranokstantis fizikalizmo ribas ir oponuojantis filosofinei scholastikai. Irodinejjama, kad Rorty fizikalizmą grindžia metafilosofinė motyvacija - siekis parodyti, kad fizikinès deskripcijos apsaugo nuo nepamatuotos pretenzijos į transcendentiškai angažuotą, neva objektyvų ir universaliai taikomą žinojimą. Svarstoma "sąmonės", kaip tuščios koncepcijos, galimybė, kartu ginant Rorty eliminatyvizmą nuo kritikos dèl neva esančio pasidavimo scientizmui. Prieinama išvada, kad Rorty filosofijos kontekste sąmonės koncepcija laikytina idealistų ir natūralistų konstrukcija, nenurodančia jokio konkretaus turinio, todèl neatlaikančia materialistų kritikos. Vis dèlto net ir pasitelkus fizikinį žodyną sąmonès problematikai išskleisti, ši išsklaida nesuteikia visiško savęs pažinimo, i kurị galètų pretenduoti mokslinis žinojimas - tam padeda filosofinės, teologinès ir kitokios deskripcijos. 


\section{IVADAS}

Nors Richardo Rorty sąmonès filosofija, kiek teigtina tokią esant, yra mažai tyrinèta, pastaruoju metu visas jo filosofijos karkasas sulaukia didesnio susidomèjimo. Vis dèlto mes remsimés pirmiausia paties autoriaus tekstais (tiek tais, $\dot{i}$ kuriuos tiesiogiai referuojama, tiek nepaminètais darbe) bei bendromis jo filosofijos interpretacijomis, o kartu ir sąmonés filosofu, su kuriais tiesiogiai polemizuojama, idèjomis, padedančiomis išskleisti ir konkretizuoti paties Rorty poziciją.

Šiai išsklaidai pasirinkta aptarti metafilosofinę ${ }^{1}$ Rorty fizikalizmo motyvaciją, "sąmonès" konceptualini turiningumą bei, prisidedant prie vykstančios diskusijos ir oponuojant Jamesui Tartaglia, Rorty eliminatyvizmo kritiką.

\section{METAFILOSOFINÉ RORTY FIZIKALIZMO MOTYVACIJA}

Galima pagristai teigti, kad visa Richardo Rorty filosofija suponuoja antifundamentistinę laikysena, kuri ǐšaknyta episteminėse nuostatose. Ryškiausiai ir bendriausiais bruožais jos matyti Rorty veikale Philosophy and the Mirror of Nature (1979). Čia teigiama: „Idèja, kad gali būti toks dalykas kaip „žinojimo pamatai“ (viso žinojimo - visose srityse, praeityje, dabartyje ir ateityje) arba „reprezentacijos teorija" (visu reprezentaciju, pažistamuose žodynuose ir tuose, apie kuriuos dar net nesvajota) priklauso nuo prielaidos, kad egzistuoja koks nors a priori apribojimas“ (Rorty 1980: 9). Aprioristine nuostata, kad egzistuoja tam tikras žinojimo pagrindas, grista kantiškoji epistemologinè ir ontologinè tradicija, kuriai oponuoja Rorty. Šis episteminis nesutarimas apibrèžia ne tik filosofinę, bet ir bendrą kultūrinę laikyseną - pasipriešinimas etiniam, religiniam ir kitokiam fundamentizmui padeda kaip iš filosofiniu (episteminių) prielaidų kylantis, bet ju ribas pranokstantis veiksnys. Žodyno (arba deskripcijos) iškèlimas virš bet kokios numanomos esmès ar "tikrojo žinojimo" eksplicitiškai išskleistas ir Ror- ty sąmonės filosofijoje, kuri apibūdintina kaip fizikalistinè (kildintina iš Rorty natūralizmo) arba eliminatyvistinè (redukuojanti mentalines būsenas ì smegenų būsenas). Rorty fizikalizmą grindžia metafilosofinè motyvacija - siekis parodyti, kad fizikinès deskripcijos apsaugo nuo nepamatuotos pretenzijos į neva objektyvų ir universaliai taikomą žinojimą. Ši teigini įrodantys argumentai:

1) „sąmonè“, kaip karteziškosios filosofijos artefaktas, prilyginama Dievui kaip ankstyvosios kosmologijos artefaktui;

2) psichofizinis dualizmas laikytinas tiesiogiai lemiančiu episteminio dualizmo nuostatas;

3) verifikacionistiné pozicija laikoma daugiau pagrissta nei realistinè (tapatintina su esencialistine).

Pirmasis argumentas nurodo ortodoksišką tikejimą tam tikru reiškiniu, kurio egzistavimo patirtis nepajejgi patvirtinti ar atmesti. Šis nepajègumas atveria neribotą erdvę spekuliacijai, neva objektyviu ir universaliai taikomu žinojimu, dažniausiai grindžiamu transcendentinėmis prielaidomis. Kaip vieną tokio pobūdžio 
žinojimo pavyzdžių Rorty pateikia Dievo, kaip ankstyvosios kosmologijos artefakto, statusą ir gretina ji su karteziškuoju artefaktu, t. y. pačia sąmone. Tiek kosmologinis, tiek karteziškasis artefaktai dèl savo specifinio statuso nereikalingi paaiškinimo, bet dèl to nèra eliminuojami iš bendro kultūros lauko. Priešingai, nepaisant jų neapčiuopiamumo, negalimybės lokalizuoti erdvëje ir laike, jie įstengia palaikyti transcendencijos ambiciją. Rorty, aptardamas artefaktų reikšmę, oponuoja Nageliui: „Brandomas, Sellarsas ir Wittgensteinas paprasčiausiai stokoja "transcendencijos ambicijos", kurią Nagelis, šiuo atveju primindamas Vakaru monoteizmo teologus ortodoksus, laiko siektina" (Rorty 2007: 13). Nageliui būdinga transcendencijos ambicija laikytina priešinga Brandomo ir Sellarso kalbiniam "transcendencijos atkerèjimui" bei vitgenšteiniškajam atsisakymui žaisti kalbinį qualia žaidimą. Būtent transcendencijos ambicija priskiria Nagelį kantininku gretoms ir jo laikyseną sąmonès filosofijos atžvilgiu iškelia ị metafilosofinį lygmenį, kuriame tinkamas atsakas fundamentizmui reikalingas episteminiu nuostatu redeskripcijos.

Čia svarbu peržiūrèti episteminio ir psichofizinio dualizmu sąveika, nulemiančią pati santyki su objektu ir jo pažinimo būdu. Psichofizinio dualizmo atveju iprasta remtis perskyra tarp mentalinių ir fizikinių būsenų, episteminio dualizmo atveju ši skirtis projektuojama kaip esanti tarp pažinimui prieinamu duomenų apie objektą ir paties objekto. Nors karteziškoji revoliucija pirmiausia laikytina psichofizinio dualizmo pagrin$\mathrm{du}, \mathrm{ji}$ tiesiogiai susijusi su episteminiu dualizmu, grindžiančiu ne tik epistemo- logini tyrima, bet ir kasdieni pasaulio suvokimo būdą. Kai kasdienio pasaulio objektai imami mąstyti kaip atsieti nuo pažinimui prieinamų duomenu, atveriamas kelias transcendentinèms spekuliacijoms, kosmologiniu artefaktu igalinimui, o tokiu būdu ir universaliai taikomo fundamentistinio žinojimo issteigimui. Tai vienas didžiausiu psichofizinio, o kartu ir episteminio dualizmo pavoju, jeigu žvelgsime iš Rorty perspektyvos. Nuo jo apsaugoti gali pasipriešinimas pirmiausia psichofiziniam dualizmui: „Russellas ir Whiteheadas veikiau norèjo suvienyti pasaulio "medžiagą", nei leisti jai būti padalintai į neerdvišką sąmonę ir erdvišką materiją. Šio gesto tikslas buvo iš naujo apibrèžti medžiagą, kuri yra "ten“ tam, kad paaiškètu, jog tai ta pati medžiaga, kuri yra "priešais mūsu protą" (Rorty 1982: 328-329). Neerdviškos sąmonès ir erdviškos materijos suvienijimo gestas Rorty filosofijos kontekste laikytinas turinčiu metafilosofinę motyvacija, kadangi jis tiesiogiai lemia minètą episteminę laikyseną - transcendencijos, o kartu ir universalistinio pagrindo, pripažinimą arba atmetimą.

To paties tikslo padeda siekti ir Gilberto Ryle'o sąmonès filosofija, kurios pagrindinemis tezèmis Rorty gausiai remiasi oponuodamas karteziškajai tradicijai. Pripažintas sąmonès nepažinumas apsaugo nuo transcendentinès ambicijos lygiai taip pat, kaip neerdviškos sąmonès ir erdviškos materijos suvienijimas. Rorty laikosi Ryle'o pozicijos neigdamas griežtą spontaniško, intuityvaus vidujybès pažinumo priešpriešinimą neva kitaip pažistamai išorybei. Anot Ryle'o, "Jis [žmogus. - A. A.], pasitelkdamas savo regos juslę, gali ne tik ste- 
bèti ir tyrinèti gèlę ir, pasitelkdamas klausos juslę, klausytis varpo skambesio; jis taip pat gali reflektyviai ar intuityviai stebèti, be jokio kūniško juslès organo, dabartinius savo gyvenimo epizodus" (Ryle 2009: 4). Panaikinus prarają tarp introspektyvaus ir i išorybę nukreipto pažinimo, demistifikuojami mentaliniai ivykiai, o kartu ir pats pažinimo procesas. Tai leidžia kalbèti apie sąmonę be kosmologinio ir karteziškojo artefaktu, taigi legitimuoja fundamentizmui nepalankų fizikalistinį žodyną.

Fizikalistinis žodynas atitinka verifikacionistinę intenciją praplèsti žodyną randant bendrą sutarimą dèl nuoseklių santykiu tarp skirtingu propozicijų. $X$ esmè tiesiogiai priklauso nuo vartojimo aplinkybiu ir yra atvira mokslo ar kitu faktoriu įtakai, keičiančiai sąveiką tarp propoziciju, kurios ir lemia pačią $X$ esmę; o realistinè intencija, kurią čia priešpriešiname verifikacionistinei, $X$ esmę grindžia ne santykiais tarp skirtingu propoziciju bet nekintama $X$ prigimtimi, kurią siektina surasti. Taigi realistinè pozicija palanki fundamentizmui ir pretenduoja i̇ objektyvų, nuo kintančių aplin- kybių nepriklausomą žinojima, o verifikacionistinė žinojimą grindžia kintančiais santykiais. Rorty atveju ši priešprieša svarbi ne tik metafilosofiškai, bet ir dar kartą kritikuojant Nageli - „NagelioSearle'o manymas, kad turime ikilingvistini tikrosios esmės, kuri nèra sugriebta mūsų žinojime apie propozicijų tiesas, žinojima, yra ypatingas realizmo atvejis" (Rorty 1982: 340). Kaip matome, Rorty tapatina Nagelio realizmą $a^{3}$ su esencialistine laikysena episteminiu nuostatu atžvilgiu, todèl, kritikuodamas jo įsitikinimą apie ikilingvistini žinojima, kartu kritikuoja ir pretenziją $\mathfrak{i}$ universalistinę ir nekintančią tiesą. Oponuodamas Nageliui, Rorty užima verifikacionistinę pozicija, leidžiančią grịsti $X$ esmę santykiais tarp skirtingu propoziciju, o ne nekintama $X$ prigimtimi.

Taigi Rorty fizikalizmas, o kartu ir visa jo sąmonès filosofija, kiek įmanoma teigti ją esant, grịsta metafilosofine motyvacija - siekiu irodyti, kad pasikliovimas fizikiniu žodynu apsaugo nuo nepamatuotos pretenzijos i neva objektyvų, transcendentiškai angažuotą fundamentistinį žinojimą.

\section{"SAQMONE்" KAIP TUŠČIA KONCEPCIJA}

Kaip parodème trečiuoju argumentu, verifikacionizmo - realizmo kontroversija neišvengiamai nukreipia lingvistinio posūkio link. Jeigu pritarsime nuostatai, kad sąmonė nèra ikikalbinis artefaktas, turèsime pripažinti jos konceptualini tuštumą. Kitaip sakant, teigsime, kad prieškalbinè sąmonè yra kontradikcija, nes jos turinį atskleidžia kalbejjimas apie pojūčius, o ne pojūčiai patys savaime. $\breve{S}_{i}$ teigini irodantys argumentai:
1) idealistų ir natūralistų pasitelkiama sąmonès koncepcija yra neturininga, todèl neatlaikanti materialistų kritikos;

2) perskyra tarp žinojimo ir deskripcijos igalina filosofini tyrimą kaip netapatų moksliniam pažinimui, bet ji turiningai papildanti.

Prieš išskleidžiant šiuos argumentus dera paminèti, kad pats Rorty, nors dèl kertinių savo filosofijos principų dažnai 
priskiriamas natūralistams, polemizuodamas su sąmonés filosofais, palaiko materialistinę poziciją. Kita vertus, šios pozicijos palaikymas jam netrukdo kalbèti apie fizikinio (arba natūralistinio) žodyno pranašumą kitų žodynų atžvilgiu analizuojant sąmonès procesus. Reikètų atskirai kelti klausima, kiek apskritai prasminga skirti minètas pozicijas, tačiau mums šiuo atveju svarbi perskyra tarp natūralistinès ir idealistinės versus materialistinès laikysenos. Kitas svarbus aspektas yra psichikos - fizikos (mental - physical) perskyros gretinimas su moralumo - amoralumo (moral - non-moral) perskyra. Pastaruju perskyru gretinimas leidžia Rorty idealistinę ir natūralistinę poziciją priešinti su materialistine, kadangi dvi pirmosios numato išskirtini žmogaus statusa, kuri grindžia Geist ar tam tikra dieviška tvarka (idealizmo atveju), kartu įsteigianti ontologiškai išaknytą moralès pagrinda, arba mokslo nepajègumas atsakyti i klausimus apie žmogu (natūralizmo atveju) ${ }^{4}$. „Taigi tiek idealistai, kurie išrado psichiką kaip dieviškumo ịpėdini, tiek natūralistai, kurie norëjo mąstyti žmogu kaip nedievišką kartu jo netrivializuodami, sutarè, kad miglotumas, kuri reprezentuoja „sąmonès" koncepcija, buvo tinkama tema filosofinei refleksijai“" (Rorty 1982: 345). Kitaip sakant, sąmonės koncepcija laikytina idealistų ir natūralistų konstrukcija, nenurodančia i jokị konkretų turinį. Dèl to Rorty siūlo „liautis bijoti mokslo ir vulgaraus materializmo" (ten pat), demistifikuojančio sąmonès koncepciją.
Vis dèlto sąmonès, kaip filosofiškai neturiningos koncepcijos, klausimo perdavimas išimtinai materialistiniam ir scientistiniam pažinimui nepadaro jo filosofiškai nerelevantišku. Čia pasitarnauja perskyra tarp mokslinio žinojimo (arba pažinimo) ir filosofinès deskripcijos. Jeigu ikikalbinis sąmonès pažinimas imanomas tik kaip mokslinis projektas, šio pažinimo deskripcija laikytina filosofiškai turininga. Būtent deskripcijos ir žinojimo atskyrimas pagrindžia sąmonès koncepcijos filosofinį tuštuma, kuri užpildyti pajègus materialistinis mokslas ir nuo jo neatsieta filosofine deskripcija. Tai nereiškia, kad visas subjekto pažinimas perleidžiamas scientistiniam tyrimui, kadangi pats Rorty pripažista mokslinès terminijos (ne žinojimo, bet būtent terminijos) nepakankamumą savižinai: "Sakyti, kad materialistinio mokslo (o koks dar gali būti mokslas?) terminija yra nepakankama, kad pateiktų mums savo vaizda, yra, be abejo, teisinga" (Rorty 1982: 345). Taigi, net ir pasitelkus fizikinį žodyną sąmonės problematikai išskleisti, ši išsklaida nesuteikia visiško savęs pažinimo, i kuri galètu pretenduoti mokslinis žinojimas - tam pasitarnauja filosofinès, teologinès ir kitokios deskripcijos. Kita vertus, nėra aišku, kaip reikètų interpretuoti Rorty pozicijos dvilypumą, kai, pavyzdžiui, deskripcija prieštarauja žinojimui, arba kokie tikslūs parametrai skiria žinojimą nuo deskripcijos, kad šie du kintamieji nebūtu painiojami.

\section{RORTY ELIMINATYVIZMO KRITIKA}

Rorty pozicija sąmonès filosofijos atžvilgiu iš esmès yra šiek tiek modifikuo- tas Ryle'o tradicijos pratęsimas. Nors būtų sudètinga tiksliai ìvardinti Ryle'o 
pažiūrų ittaką dèl jų nemenko persiklojimo su Wittgensteino filosofija, kuri taip pat yra viena svarbiausių bei apima visą Rorty filosofijos karkasa, Ryle'o mintis reikšminga kaip užklausianti pačią prieigos prie vidinių būsenu galimybę. Viena vertus, šis užklausimas leidžia atsisakyti esencialistinès pretenzijos, bet, kita vertus, atveda Rorty prie eliminatyvizmo. Šis eliminatyvizmas kritikuotinas kaip pernelyg lengvai pasiduodantis scientizmui (tokios pozicijos laikosi James Tartaglia), tačiau mes méginsime užginčyti šią poziciją ir parodyti, kad Rorty eliminatyvizmas išlaiko kritišką distanciją su scientizmu kaip pernelyg vienmatiška sistema.

Kaip parodème anksčiau, Rorty sąmonès filosofijos ribose teikia pirmenybę fizikiniam žodynui, tačiau atsisako spręsti iprastus sąmonès filosofijos klausimus; šis apsisprendimas didele dalimi nulemtas nusivylimo scholastiniu diskusiju pobūdžiu, iš kurių išsiskiria Ryle'o-Dennetto $^{5}$ tradicija, igalinusi kalbejjimą apie isitikinimus ir pojūčius be kalbejjimo apie sąmonès „miglotumą“6. Atsisakymas kalbèti apie sąmonę scholastiniu būdu yra vienas iš eliminatyvizmo motyvu, tačiau jis neatveda prie scientistinès laikysenos, nebent tokiais pat scientizmo atstovais laikysime ne tik Ryle'a, bet ir Wittgensteiną. Ši pati laikysena grindžia ir fizikinio žodyno iškèlimą virš „,miglotų“ sąmonès sampratų, tačiau neigalina jo kaip vienintelio ir nepakeičiamo. Anot Rorty kritiko Tartaglia, „...fizikinès, kaip priešpriešinamos bet kokiai kitai, deskripcijos formos galimybè būti visa įimančia, jo [Rorty. - A. A.] atveju tampa nepaaiškinama paslaptimi - atletinės ar ekonominės deskripcijos neveiktų..." (Tartaglia 2016: 23). Čia ir kitur pasirodanti Rorty eliminatyvizmo, kaip psichinių deskripcijų redukavimo i̇ fizikines ir kitų deskripciju neva „neveikimo“, kritika nèra pagrìsta, kadangi nepaisoma vieno esminių Rorty filosofijos bruožų - žodynų daugio pripažinimo. Šis argumentas atremia visą kritika, kuri Rorty eliminatyvizmą kaltina scientizmu, nes scientizmui būtinas objektyvios tiesos monopolis yra paties Rorty kritikos objektas.

Rorty gamtos mokslų žodyną vertina kaip naudingą prognozavimui ir kontrolei, bet šalia jo teigia esant savižinai būtinus moralinius, politinius, meninius ir kitus žodynus (Rorty 1982: 346). Taigi, atsižvelgiant i pasikartojančias bendras filosofines nuostatas, būtų klaidinga laikyti Rorty sąmonès filosofija, kiek tokia yra i̇manoma, scientistine, kadangi fizikinis žodynas čia veikiau reiškia atsiribojimą nuo neprasmingos filosofinès scholastikos nei nekritišką pasidavimą scientizmui.

\section{IŠVADOS}

1. Rorty sąmonès filosofija įmanoma kaip metafilosofinis projektas, peržengiantis fizikalizmo ribas ir oponuojantis filosofinei scholastikai. Fizikalizmas, o kartu ir visa Rorty sąmonès filosofija, grista metafilosofine motyvacija, remian- tis fizikiniu žodynu, apsaugo ją nuo nepamatuotos pretenzijos i neva objektyvų, transcendentiškai angažuotą fundamentistini žinojimą.

2. Rorty filosofijos kontekste sąmonès koncepcija laikytina idealistų ir natūralis- 
tų konstrukcija, nenurodančia i jokị konkretu turini, todèl neatlaikančia materialistų kritikos. Vis dèlto, net ir pasitelkus fizikini žodyną sąmonès problematikai išskleisti, ši išsklaida nesuteikia visiško savęs pažinimo, i kuri galètu pretenduoti mokslinis žinojimas - tam pasitarnauja filosofinès, teologinès ir kitokios deskripcijos. Kita vertus, nėra aišku, kaip reikètu interpretuoti Rorty pozicijos dvilypuma, kai, pavyzdžiui, deskripcija prieštarauja žinojimui, arba kokie tikslūs parametrai skiria žinojimą nuo deskripcijos, kad šie du kintamieji nebūtų painiojami.

3. Žodynų daugio pripažinimo argumentas atremia visą kritiką kuri Rorty eliminatyvizmą kaltina scientizmu, nes scientizmui būtinas objektyvios tiesos monopolis yra paties Rorty kritikos objektas.

\section{Literatūra}

1. Dennett, Daniel C. 1981. Brainstorms: Philosophical Essays on Mind and Psychology. USA: MIT Press.

2. Furlong, John. 1988. Scientific Psychology as Hermeneutics? Rorty's Philosophy of Mind. Philosophy and Phenomenological Research 48: 489-503. International Phenomenological Society.

3. Nagel, Thomas. 2013. Mortal Questions. New York: Cambridge University Press.

4. Rorty, Richard. 1980. Philosophy and the Mirror of Nature. Princeton, New Jersey: Princeton University Press.

5. Rorty, Richard. 1982. Contemporary Philosophy of Mind. Synthese 53: 323-348. Springer.

\section{Nuorodos}

1 Čia ir kitur „metafilosofijos“ terminas vartojamas kaip reiškiantis pačios filosofijos tikslų, galimybių ir metodų peržiūrẻjimą; jis taip pat nurodo episteminę laikysena, apibrèžiančią santyki su kitomis filosofijos šakomis (šiuo atveju ypač su sąmonès filosofija). Taigi „Rorty metafilosofinis projektas" reiškia pretenzijos kurti užbaigtą (sąmonès) filosofijos sistemos atsisakyma, vis dèlto siekiama peržiūrèti anksčiau sukurtas sistemas ir nustatyti jų vietą bendroje filosofinès žinijos srityje.

2 Kaip parodyta anksčiau, Rorty ir Ryle'o pozicijos sutampa dèl ontologinio monizmo, tiesiogiai vedančio fizikalizmo link. Čia svarbu paminèti, kad esama pozicijos, teigiančios ne Rorty fizikalizmą, bet funkcionalizmą, kuris čia pat ir užginčijamas (Furlong 1988), tačiau mes tik iš dalies laikome šią diskusiją esant prasminga, nes ji neišskleidžia

6. Rorty, Richard. 2007. Philosophy as Cultural Politics: Philosophical Papers, Volume 4. New York: Cambridge University Press.

7. Ryle, Gilbert. 2009. The Concept of Mind. Abingdon: Routledge.

8. Šaulauskas, Marius Povilas. 1997. Postmoderniosios musès skrydis: sociologija ir postpozityvistinè Rorty analitika. Sociologija. Mintis ir veiksmas 1 (1), 1997.

9. Tartaglia, James. 2016. Rorty's Philosophy of Consciousness. Consciousness and the Great Philosophers: What would they have said about our Mind-Body Problem? Abingdon: Routledge.

metafilosofinès Rorty sąmonès filosofijos motyvacijos, kuri laikytina būtina sąlyga siekiant aptarti Rorty sąmonès filosofijos įmanomybę.

3 Pats Nagelis savo realizmą grindžia faktų, esančių už žmogui prieinamų koncepcijų, egzistavimu (Nagel 2013: 171).

4 Natūralistinei, antiidealistinei tradicijai čia priskirtini Russellas, Whiteheadas, Jamesas, Dewey.

5 Vienas tokio kalbejjimo pavyzdžių yra Dennetto pasažas apie pokalbi, kurio metu užklausiami vieno iš jo dalyvių isitikinimai, ir tokiu būdu jis turi teisę isižeisti, jeigu teigiant, $\operatorname{kad} p$, atsakoma užklausiant, kas sukèlè įsitikinimą $p$, nes tai reiškia, kad jis yra tiesiog sukeltas kokios nors priežasties (Dennett 1981: 180).

6 Rorty eksplicitiškai remiasi šios tradicijos prielaidomis, leidžiančiomis nekelti psichikos / fizikos klausimo; daugiau žr. (Rorty 1982: 326). 